\title{
Synbiotic preparation with Lactic acid bacteria and inulin as a functional food: In vivo evaluation of microbial activities, and preneoplastic aberrant crypt foci
}

\author{
Chaiyavat CHAIYASUT ${ }^{1}$, Thanawat PATTANANANDECHA ${ }^{1}$, Sasithorn SIRILUN ${ }^{1}$, Prasit SUWANNALERT ${ }^{2}$, \\ Sartjin PEERAJAN ${ }^{3}$, Bhagavathi Sundaram SIVAMARUTHI ${ }^{1 \star}$
}

\begin{abstract}
Host microbiome and metabolome are associated with the incidence of colorectal cancer (CC), one of the major health problems in developed countries. The pro and prebiotic supplementation helps to improve the host health. Inulin is one such prebiotic used for the enhancement of naïve probiotic bacterial population. This paper explains the impact of inulin (PRE) extracted from Jerusalem artichoke (JA), Lactobacillus plantarum HII11 (PRO), and synbiotic (SYN; inulin + L. plantarum HII11) preparation on Azoxymethane mediated CC induced rat model with respect to changes in microbial load, microbial enzymes, and preneoplastic aberrant crypt foci. The results suggested that the PRE and SYN supplementation effectively reduced the selected pathogenic bacteria (Salmonella spp., and Escherichia coli), microbial enzymes and increased the probiotic load. The intervention of SYN significantly reduced the colonic ACF in CC model. The study results revealed that the supplementation of SYN diet (inulin and L. plantarum HII11) protects the AOM-mediated colon cancer induced host.
\end{abstract}

Keywords: inulin; L. plantarum; probiotic; prebiotic; synbiotic.

Practical Application: The study results help to develop functional food to improve the human health.

\section{Introduction}

Colorectal cancer (CC) is one of the major health problems with the vast incidence in developed countries. Currently, the incidence and mortality of CC increased rapidly in Asian countries (Pourhoseingholi, 2012). Diet, environment and lifestyle play a significant role in carcinogenesis. The increase in CC incidence is parallel with economic development and adoption of a western way of life (Center et al., 2009). Epidemiological studies suggested that consumption of high-fat diet, red meat, and processed meat, could be associated with the contribution of CC risk (Huxley et al., 2009; Chan et al., 2011). However, fiber-rich diet appeared to be protective against CC (Riboli \& Norat, 2003). Scientific evidences revealed that colonic microflora have a significant role in the cause of CC by altering the metabolome and the transcriptome of the host (Louis et al., 2014; Ohtani, 2015).

Live microbes with a beneficial impact on host system upon consumption are known as probiotics. Most of the probiotics are lactic acid bacteria in nature such as Lactobacillus, Leuconostoc, Pediococcus, Lactococcus, and Streptococcus, etc. Several probiotic based clinical trials were conducted to address the advantageous role of probiotics in pathological conditions like lactose intolerance, antibiotic-induced diarrhea, gastroenteritis, constipation favorable against diseases caused by an imbalance of the colonic microflora, and anti-colon tumor effect (Iannitti \& Palmieri, 2010). The prebiotics, naturally occurring non-digestible food compounds, are responsible for the favorable changes in host system by positively regulating the growth and/ or activity of probiotic bacteria, resisting especially in colon region (Gibson et al., 2010). Inulin, existing in the form of oligo- and polysaccharides has been recognized as a prebiotic with desirable traits like stability at gastric acidity, accessiblility to mammalian enzymes and gut microbes. Inulin extracted from Jerusalem artichoke (JA), exhibited a prebiotic activity, especially for Lactobacillus plantarum and showed the antimicrobial response against Escherichia coli and Salmonella enterica serovar Typhi in vivo (Pattananandecha et al., 2015). We also demonstrated the prebiotic and anti-colon cancer nature of JA-inulin in azoxymethane (AOM)-induced rat model. In detail, inulin administration positively regulated the population of representative probiotic strains and suppresses the pathogenic strains (Pattananandecha et al., 2016).

The retaining of microbial balance in the human gut plays a significant role in preventing diseases (Guinane \& Cotter, 2013; Slavin, 2013). It is known that appropriate pre and probiotic supplementation enhance the survival and activities of a distinct group of microbes both in-vitro and in-vivo (Anandharaj et al., 2014). Pro and prebiotic candidates aids the suppression of harmful bacterial growth and releases of genotoxic, and carcinogenic substances (phenol, $p$-cresol, and phenolic compounds) (Burns \& Rowland, 2000) and CC associated bacterial enzymes ( $\beta$-glucuronidase, nitroreductase, and azoreductase) (Rowland et al., 1998). 
Synbiotic, the combination of pre and probiotic, has synergistic effects on promoting the growth of existing beneficial strains in the colon, and improving the survival, attaching and growth of newly introduced probiotic strains. Synbiotic intervention showed improved health benefits to the host compared to either unaided probiotic or prebiotic supplementations (Liong, 2008). To the best of the authors' knowledge, there are no detailed reports on the beneficial effect of a synbiotic preparation containing JA-inulin and L. plantarum HII11. Thus, we executed the experiments with prebiotics (Inulin), probiotic (L. plantarum HII11), and synbiotic (Inulin + L. plantarum HII11) preparations to assess the effect on AOM-induced colon cancer in a rat model.

\section{Materials and methods}

\subsection{Bacterial strain and chemicals}

The probiotic bacterium, L. plantarum HII11 was acquired from Health Innovation Institute, Chiang Mai, Thailand. Azoxymethane (AOM) was purchased from Wako Pure Chemical Industries, Ltd. Osaka, Japan. $p$-Nitrophenyl- $\beta$-d-glucuronide, Trisodium 3-hydroxy4-(4'-sulphonatonaphthylazo) naphthalene-2,7-disulphonate (Amaranth), $p$-Nitrobenzoic acid, ammonium sulfamate and $\mathrm{N}$-(1-Naphthyl) ethylenediamine dihydrochloride (NEDD) were bought from Sigma-Aldrich Co. LLC, St. Louis, MO, USA. Hydrolyzed inulin was obtained from Health Innovation Institute, Chiang Mai, Thailand.

\subsection{Animals and diets}

The National Laboratory Animal Center (NLAC), Mahidol University, Bangkok, Thailand provided the sum of 72 Sprague-Dawley male rats at the age of 4-5 weeks. The lab acclimatized (2 weeks) animals were randomly divided into six groups of 12 rats each ( 3 control groups \& 3 AOM treated groups). All the rats were maintained at $21-25^{\circ} \mathrm{C}$ with 12 hours of light-dark cycles and water and diets were given ad libitum. After 2 weeks of normal diet (Mouse and rat diet No. 082, NLAC, Thailand), animals were fed with normal diet (Control), diet containing $10 \%$ of inulin (PRE), diet containing $10^{8}-10^{9} \mathrm{CFU} / \mathrm{g}$ of probiotic strain (PRO), and diet containing $10^{8}-10^{9} \mathrm{CFU} / \mathrm{g}$ probiotic strain with $10 \%(\mathrm{w} / \mathrm{w})$ inulin (SYN) for 17 weeks. All rats in the AOM-treated group were subjected to subcutaneous injection of AOM ( $15.0 \mathrm{mg} / \mathrm{kg}$ body weight) at week 8 and 9 of the experimental period. Body mass and feed intakes were measured weekly. Animal experiments were performed as per the regulations and approval of an ethical committee of Faculty of Pharmacy, Ubon Ratchathani University, Ubon Ratchathani, Thailand (24/2009/Research).

\subsection{Measurement of cecal content weight and cecal pH}

All the animals were sacrificed after 17 weeks of experimental diets, and the whole cecum were excised and weighed. Then the cecal pH was measured (Metrohm- 691) after slitting the cecum open.

\subsection{Bacterial enumeration and detection of microbial enzymes}

The representative fecal bacterial (Lactobacillus spp., Bifidobacteria spp, Escherichia coli and Salmonella spp.) load was determined using plate count method as detailed in our previous study (Pattananandecha et al., 2016) and the results were represented as $\log$ difference between before and after the treatments. Bacterial enzymes such as $\beta$-glucuronidase, azoreductase, and nitroreductase were determined by the spectrophotometric method as described previously (Pattananandecha et al., 2016).

\subsection{Examination of putrefactive compounds and organic acids}

The content of organic acids (lactic, acetic, propionic, and butyric acids) and putrefactive compounds (indole, phenol, and $p$-cresol) in the rat feces were estimated using high-performance liquid chromatography (HPLC) as described previously (Pattananandecha et al., 2016).

\subsection{Microscopy}

The colon samples were collected after sacrificing the experimental animals at the end of study period. Then the number of ACF were counted by staining with $0.2 \%$ methylene blue using the microscope (Olympus/Bx60) as reported previously (Pattananandecha et al., 2016).

\subsection{Statistical analysis}

All the analyses were performed in triplicates and the results were represented as mean \pm SD. The values were analyzed by one-way ANOVA and Duncan studentized range test using SPSS version 17 (Chicago, SPSS Inc, U.S.A). A significant difference was calculated at $p<0.001-0.05$.

\section{Results and discussion}

\subsection{Body weight, feed intake, cecal weight, and $p H$}

Body weight gain (21 weeks) in rats fed with PRO $(319 \pm 25.88 \mathrm{~g})$, PRE $(325 \pm 36.25 \mathrm{~g})$ and SYN $(320 \pm 28.28 \mathrm{~g})$ diets were increased compared to rat fed with the control diet $(305 \pm 25.07 \mathrm{~g} ; p<0.05)$ and the weight of AOM-treated control rats $(280 \pm 22.80 \mathrm{~g})$ was significantly lower than the naive rats $(305 \pm 25.07 \mathrm{~g}$; $p<0.05)$. PRO and SYN supplementation significantly $(p<0.05)$ improved the body mass of the AOM-treated rats. Moreover, PRE supplementation improved the weight of AOM-treated rats $(313 \pm 22.52 \mathrm{~g})$ than PRO and SYN intervention $(283 \pm 15.06 \mathrm{~g}$ and $296 \pm 23.26 \mathrm{~g}$, respectively; Table 1).

All tested interventions (PRO, PRE, and SYN) did not affect the feed intake among the experimental animals. The cecal weight of the rats fed with PRE, and SYN diets were significantly higher compared to respective controls $(p<0.001)$ and PRO rats. The cecal $\mathrm{pH}$ of the rats fed with PRE, and SYN diets were significantly low than respective controls $(p<0.001)$ and PRO rats (Table 1). 
The results showed that PRE and SYN diet increased the cecal weight and reduced the cecal $\mathrm{pH}$ in AOM (Table 1), which was due to the colonic bacterial fermentation of inulin resulting in the release of organic acids and increased biomass (Kolida et al., 2002; Rossi et al., 2005). The fermentation of prebiotic inulin by newly added probiotic strain and the existing beneficial strains may modulate the population of bacteria in the gut (Kolida \& Gibson, 2011; Raman et al., 2013), which may also influence the microbial balance in the colon. Thus, we estimated the representative probiotic, and pathogenic bacterial genus upon various supplementations.

\subsection{Bacterial enumeration}

The changes in the selected fecal bacterial load are shown in Figure 1. The results are represented as log difference between before and after the treatments. A significant level of increase in the population of Lactobacillus spp. and Bifidobacterium spp. was observed in PRO $(p<0.01)$, PRE $(p<0.001)$, and SYN $(p<0.001)$ diets compared to control in both AOM-treated and non-treated groups. Notably, PRE, and SYN diets considerably increased the selected probiotic strains than PRO diet in both AOM-treated and non-treated groups. The log CFU values of representative pathogenic strains E. coli and Salmonella spp. were found to be significantly $(p<0.001)$ reduced upon PRO, PRE, and SYN supplementation in AOM-treated and non-treated groups (Figure 1).

The results suggested that all studied supplements significantly ( $\mathrm{p}<0.01-0.001)$ promoted the growth of Lactobacillus spp., and Bifidobacteria in both naïve (0.10-0.56 and 0.42-1.43 log CFU/g of feces, respectively), and AOM-treated (0.14-0.38 and 0.34-1.05 log CFU/g of feces, respectively) animals compared to controls (-0.45- -0.20 and $-0.60-0.03 \mathrm{log} \mathrm{CFU} / \mathrm{g}$ of feces, respectively) (Figure 1A, B). The selected pathogenic strains,

Table 1. Influence of probiotic, and synbiotic on weight gain, feed intake, cecal weight and cecal $\mathrm{pH}$ of rats.

\begin{tabular}{lcccc}
\hline \multicolumn{1}{c}{ Group } & Weight gain $(\mathbf{g})$ & Feed intake $(\mathbf{g} / \mathbf{d})$ & Cecal weight $(\mathrm{g})$ & Cecal $\mathbf{~ p H}$ \\
\hline Control & $305 \pm 25.07$ & $22.7 \pm 0.26$ & $2.45 \pm 0.74$ & $7.49 \pm 0.22$ \\
Control + AOM & $280 \pm 22.80$ & $22.6 \pm 0.13$ & $2.81 \pm 0.45$ & $7.64 \pm 0.16$ \\
PRO & $319 \pm 25.88$ & $22.8 \pm 0.50$ & $2.81 \pm 0.39$ & $7.44 \pm 0.19$ \\
PRO + AOM & $283 \pm 15.06$ & $22.5 \pm 0.24$ & $2.82 \pm 0.83$ & $7.55 \pm 0.22$ \\
PRE & $325 \pm 36.25$ & $22.6 \pm 1.10$ & $5.96 \pm 0.85^{\star * *}$ & $6.51 \pm 0.22^{\star * *}$ \\
PRE+AOM & $313 \pm 22.52^{\dagger}$ & $22.6 \pm 0.80$ & $5.56 \pm 0.98^{\dagger \dagger \dagger}$ & $6.61 \pm 0.13^{\dagger \dagger \dagger}$ \\
SYN & $320 \pm 28.28$ & $22.2 \pm 0.77$ & $6.10 \pm 0.89^{* * \star}$ & $6.48 \pm 0.12^{\star * \star}$ \\
SYN + AOM & $296 \pm 23.26$ & $21.9 \pm 0.65$ & $5.31 \pm 0.49^{\dagger \dagger \dagger}$ & $6.42 \pm 0.11^{\dagger \dagger \dagger}$ \\
\hline
\end{tabular}

All the values are mean $\pm \mathrm{SD}\left(\mathrm{n}=12\right.$ per group). ${ }^{* *} p<0.001$ represents the significantly differed from naive control group. $\dagger p<0.05$. $\dagger \dagger \dagger p<0.001$ represents the significantly differed from AOM treated- control group.
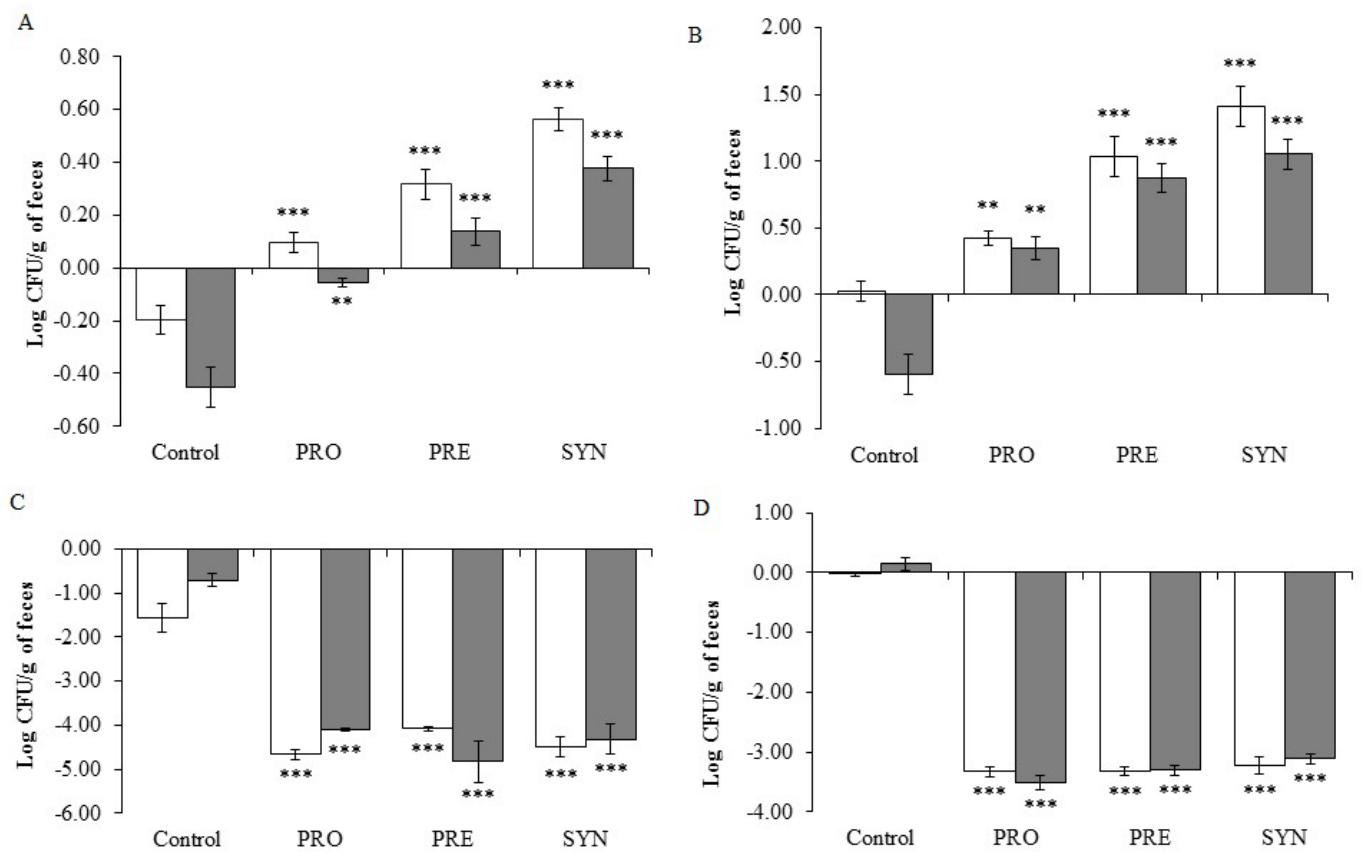

Figure 1. Changes in the bacterial population (End-Start) upon various treatments (CFU/g of feces). Naïve ( $\square$ ) and AOM-treated ( $\square$ ). Lactobacillus spp. (A), Bifidobacteria (B), Escherichia coli (C) and Salmonella spp. (D). Values are the mean \pm SD. ${ }^{* *} \mathrm{p}<0.01 \mathrm{vs}$ control group; ${ }^{* * *} \mathrm{p}<0.001 \mathrm{vs}$ control group. 
E. coli, and Salmonella spp., were drastically reduced after the PRO, PRE, and SYN supplementation in naïve (-4.67- -4.08 and -3.33- -3.23 log CFU/g of feces, respectively), and colon cancer induced (-4.82- -4.11 and $-3.51--3.07 \log$ CFU/ $g$ of feces, respectively) animals compared to controls (-1.57 - 0.71 and -0.02 - $0.14 \log$ CFU/g of feces, respectively) (Figure 1C, D).

\subsection{Organic acids and putrefactive compounds}

The inhibitory action of probiotic on pathogenic bacteria is possibly by the production of short-chain fatty acids (SCFA), lactic acid, antimicrobial compounds, and the competitive nature of probiotic bacteria for nutrients and physical attachment sites. Moreover, probiotics help to activate and enhance the host immune system, which subsequently suppresses the growth of potentially pathogenic bacteria such as E. coli, S. Typhi and C. perfringens (Cummings et al., 2001; Callaway et al., 2012). SCFAs and lactate are the end-products of microbial fermentation of polysaccharides and oligosaccharides (Pan et al., 2009). These acids play an important role in the maintenance of gut health, intestinal morphology and function (Ruemmele et al., 2003; Fung et al., 2011). Lactate improves the gut health by inducing the cell migration and cell clusters (Hirschhaeuser et al., 2011). Butyrate is a preferred energy source for colonocytes, lowering the luminal pH, (Raman et al., 2013), involved in cell cycle processes like proliferation, differentiation, and apoptosis (Siavoshian et al., 2000; Le Leu et al., 2003; Pool-Zobel et al., 2005; Comalada et al., 2006; Waldecker et al., 2008). The reports revealed that propionate and acetate can induce apoptosis in human colorectal carcinoma cell lines through the loss of mitochondrial transmembrane potential, generation of ROS, caspase-3-processing, and nuclear chromatin condensation (Hosseini et al., 2011).

The concentration of fecal organic acids in normal and AOM-treated rats after PRO, PRE, and SYN diets are shown in Figure 2. All tested organic acids (acetic, propionic, butyric, and lactic acid) significantly $(p<0.001-0.05)$ increased in rats fed with PRE, and SYN preparation. However, PRO diet did not affect the acid content; there was no significant difference between control, and AOM-treated rats. PRE, and SYN supplementation significantly $(p<0.001)$ decreased the amount of fecal indole, phenol and $p$-cresol compared to control and PRO diet groups in both AOM-treated and non-treated groups (Figure 3).

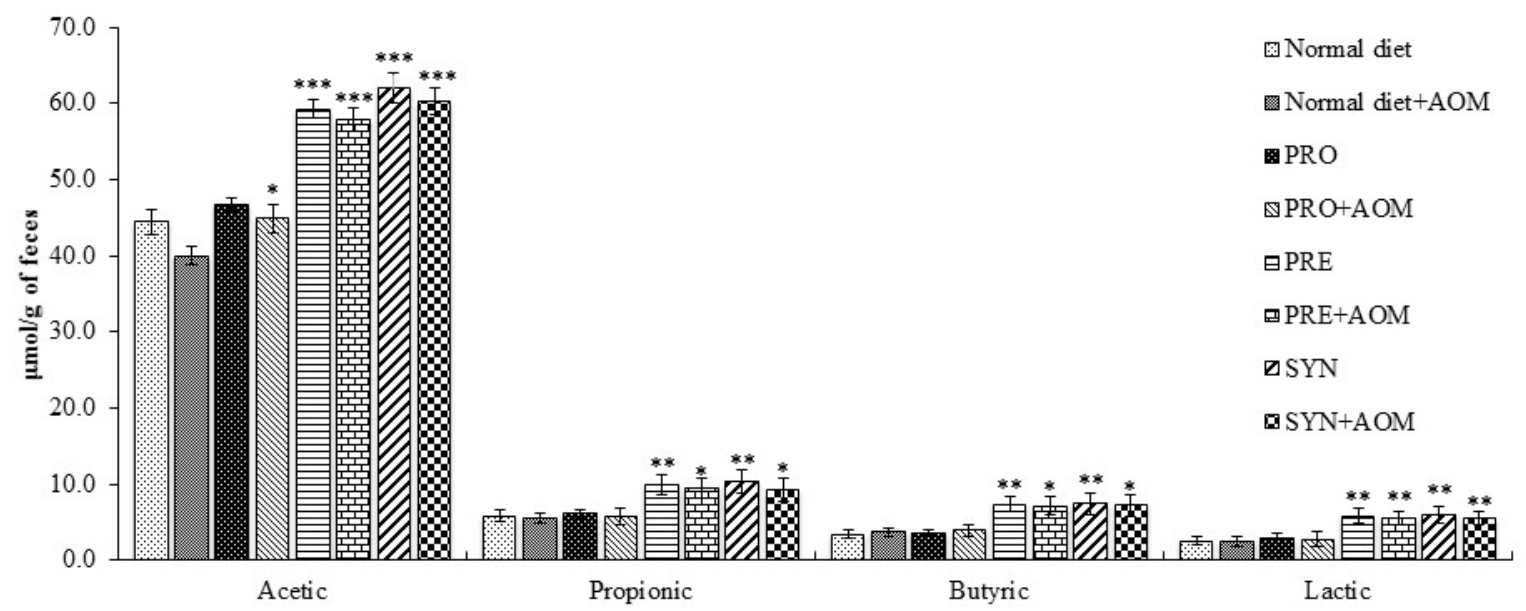

Figure 2. Profiling of organic acid content ( $\mu \mathrm{g} / \mathrm{g}$ of feces). Values are represented as mean $\pm \mathrm{SD} .{ }^{\star} p<0.05$ vs control group; ${ }^{\star *} p<0.01 \mathrm{vs}$ control group; ${ }^{* *} p<0.001$ vs control group.

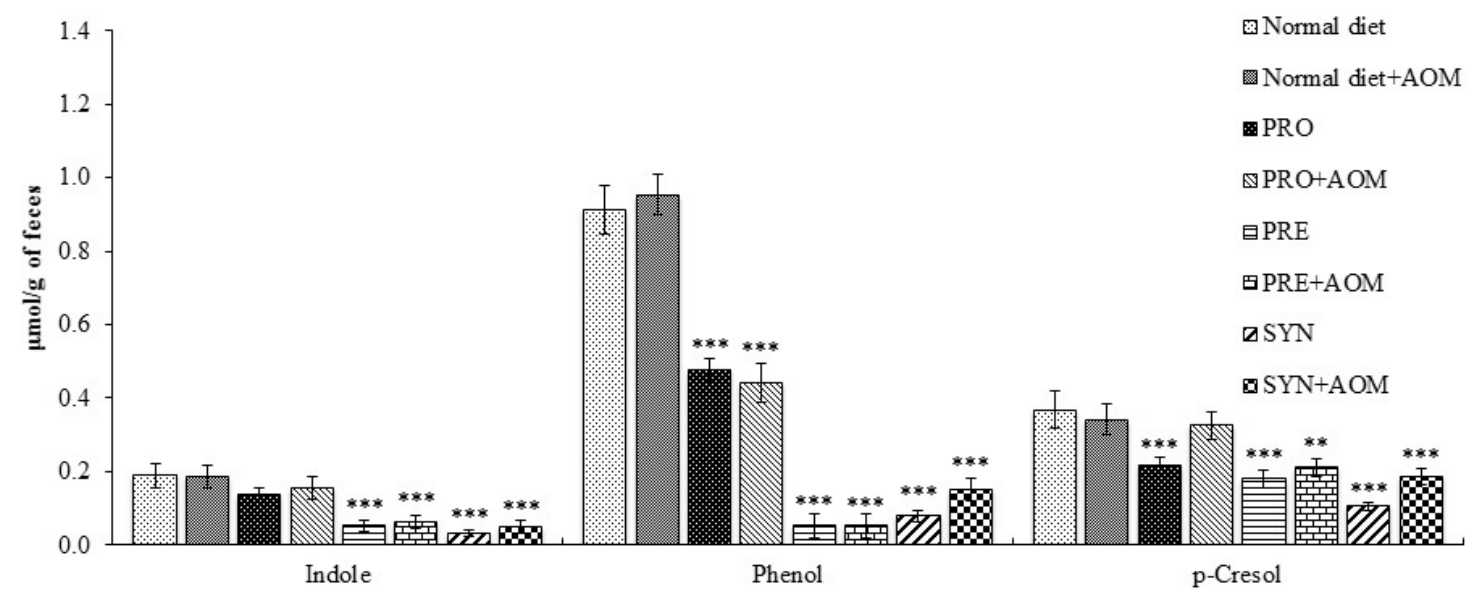

Figure 3. Concentration of putrefactive compounds among the experimental rats ( $\mu \mathrm{mol} / \mathrm{g}$ of feces). Values are the mean $\pm \mathrm{SD}$. ${ }^{* *} p<0.01 \mathrm{vs}$ control group; ${ }^{* * *} p<0.001$ vs control group. 
The results of the current study indicated that both prebiotic and synbiotic interventions possibly increased the organic acids concentration (Figure 2), which led to the reduction of colonic $\mathrm{pH}$, stimulation of beneficial bacteria, and inhibition of pathogenic bacteria. Intake of fructooligosaccharide (FOS) and galacto-oligosaccharide (GOS) improved the concentrations of total cecal SCFAs in mouse bowel (Pan et al., 2009). Noack et al. (2013) reported that the in vitro fermentation of inulin results in a high concentration of total SCFA. Femia et al. (2002) reported that the synbiotic preparation (inulin + L. rhamnosus + Bifidobacterium lactis) have anti-tumorigenic properties with respect to the caecal SCFA concentration. Moreover, synbiotic preparations are more efficient than probiotic supplements, attributed to the total SCFA concentration (Le Leu et al., 2010).

High-protein diets increase the availability of protein in the colon, which facilitates oncogenesis through the generation of toxic products (Le Leu et al., 2007). Those products include, ammonia, phenolic compounds and hydrogen sulfide (Windey et al., 2012). The phenolic compounds are formed following the bacterial degradation of aromatic amino acids such as phenylalanine, tyrosine and tryptophan (Hughes et al., 2000). Phenol and p-cresol affect the cell permeability; thereby they enhance the accessibility of a broad range of carcinogens to the colonic mucosa (Cerini et al., 2004; McCall et al., 2009; Windey et al., 2012). Indole acts as colon cancer promoter and also enhances nitrosation (Nowak \& Libudzisz, 2006). The supplementation of inulin reduced the fecal phenols (Propst et al., 2003), and fructooligosaccharide (FOS) lowered the total fecal indole and phenol concentrations in dogs (Swanson et al., 2002). An in vitro study suggested that the inulin and Clostridium difficile have the ability to reduce the concentration of phenol, indole, and p-cresol in the colon (Van et al., 2003). Synbiotic containing oligofructose-enriched inulin (OF-IN) and Bifidobacterium breve also reduces the phenol in healthy humans (De Preter et al., 2007a).

In this study, the concentration of phenol was reduced in PRO, PRE and SYN supplemented groups, while the concentration of $p$-cresol and indole were reduced only in PRE and SYN groups (Figure 3). The results indicated that the supplementation of inulin reduced the putrefactive compounds by selective stimulation of growth of Lactobacillus spp. and Bifidobacteria, which further leads to the inhibition of proteolytic bacterial growth in the colon.

\subsection{Microbial enzymes}

The effect of PRO, PRE, and SYN diets on microbial enzyme activity are shown in Table 2 .

All the supplements significantly reduced the activity of tested microbial enzymes such as $\beta$-glucuronidase (1.5-4.2 fold; $p<0.001$ ), azoreductase (1.1-1.9 fold; $p<0.001-0.05)$, and nitroreductase $(2.1-2.5$ fold; $p<0.001)$ in naive and AOM-treated groups when compared to respective controls.

The microbial enzymes such as $\beta$-glucuronidase, nitroreductase, and azoreductase are commonly produced by Bacteroides, Clostridium, and Enterobacteriaceae, which mediates the carcinogenesis (Raman et al., 2013). These enzymes have been associated with colon cancer through the formation of genotoxic and carcinogenic products (Schwabe \& Jobin, 2013; Uccello et al., 2012). The enzyme, $\beta$-glucuronidase hydrolyzes the glucuronide, which generates the potentially toxic and carcinogenic compounds (Moreno de LeBlanc \& Perdigón, 2005). Nitroreductase reduces the aromatic and heterocyclic nitro compounds to potentially mutagenic and carcinogenic $\mathrm{N}$-nitroso and $\mathrm{N}$-hydroxy compounds before converting them into aromatic amines (Hughes \& Rowland, 2000; Lee \& Lee, 2011; Moreno de LeBlanc \& Perdigón, 2005) while azoreductase reduces the azo compounds to mutagens (Rafii et al., 1990). Some Lactobacilli and Bifidobacteria have been reported for their microbial enzyme lowering activity (Yoon et al., 2000; Wollowski et al., 2001; Ouwehand et al., 2002). L. acidophilus 74-2 and FOS mediated simulation of human intestinal microbiota decreases the $\beta$-glucuronidase in the intestine and diminishes cancer risk (Gmeiner et al., 2000). The inulin supplementation can reduce the $\beta$-glucuronidase production (Rowland et al., 1998; Hijova et al., 2014). The individual intervention of oligofructoseenriched inulin, $L$. casei, and B. breve significantly decreased the $\beta$-glucuronidase activity, but supplementation of synbiotic formulation did not appear to be more beneficial than either compound alone (De Preter et al., 2007b). Whereas, the current study revealed that SYN diet significantly $(p<0.001)$ reduced the selected microbial enzymes production in AOM-treated rats, even though PRO diet also showed a significant $(p<0.001)$ reduction in the enzymes (Table 2 ). The results suggested that the inulin-containing synbiotic formulation was greatly influenced by the strain of probiotic bacteria in it.

Table 2. Profile of microbial enzyme activities of rat feces.

\begin{tabular}{|c|c|c|c|}
\hline Group & $\begin{array}{c}\boldsymbol{\beta} \text {-glucuronidase } \\
\left(\mu \text { mol nitrophenol } \mathrm{h}^{-1} \mathrm{~g}^{-1} \text { feces }\right)\end{array}$ & $\begin{array}{c}\text { Azoreductase } \\
\left(\mu \mathrm{mol} \text { Amaranth metabolised } \mathrm{h}^{-1} \mathrm{~g}^{-1} \text { feces }\right)\end{array}$ & $\begin{array}{c}\text { Nitroreductase } \\
\left(\mu \mathrm{mol} 4 \text {-Aminobenzoic acid } \mathrm{h}^{-1} \mathrm{~g}^{-1} \text { feces }\right)\end{array}$ \\
\hline Control + AOM & $0.484 \pm 0.009$ & $0.445 \pm 0.026$ & $0.299 \pm 0.032$ \\
\hline $\mathrm{PRO}+\mathrm{AOM}$ & $0.315 \pm 0.052^{\dagger \dagger \dagger}$ & $0.397 \pm 0.048^{\dagger}$ & $0.135 \pm 0.038^{\dagger \dagger \dagger}$ \\
\hline PRE & $0.089 \pm 0.042^{* * *}$ & $0.348 \pm 0.088^{\star * *}$ & $0.119 \pm 0.041^{\star * *}$ \\
\hline $\mathrm{SYN}+\mathrm{AOM}$ & $0.195 \pm 0.018^{\dagger \dagger \dagger}$ & $0.275 \pm 0.027^{\dagger \dagger \dagger}$ & $0.118 \pm 0.024^{\dagger \dagger \dagger}$ \\
\hline
\end{tabular}

All the values are mean $\pm \mathrm{SD}\left(\mathrm{n}=12\right.$ per group). ${ }^{*} p<0.05 .{ }^{* * *} p<0.001$ represents the significantly differed from naïve control group. $\dagger p<0.05 . \dagger \dagger \dagger p<0.001$ represents the significantly differed from AOM treated- control group. 

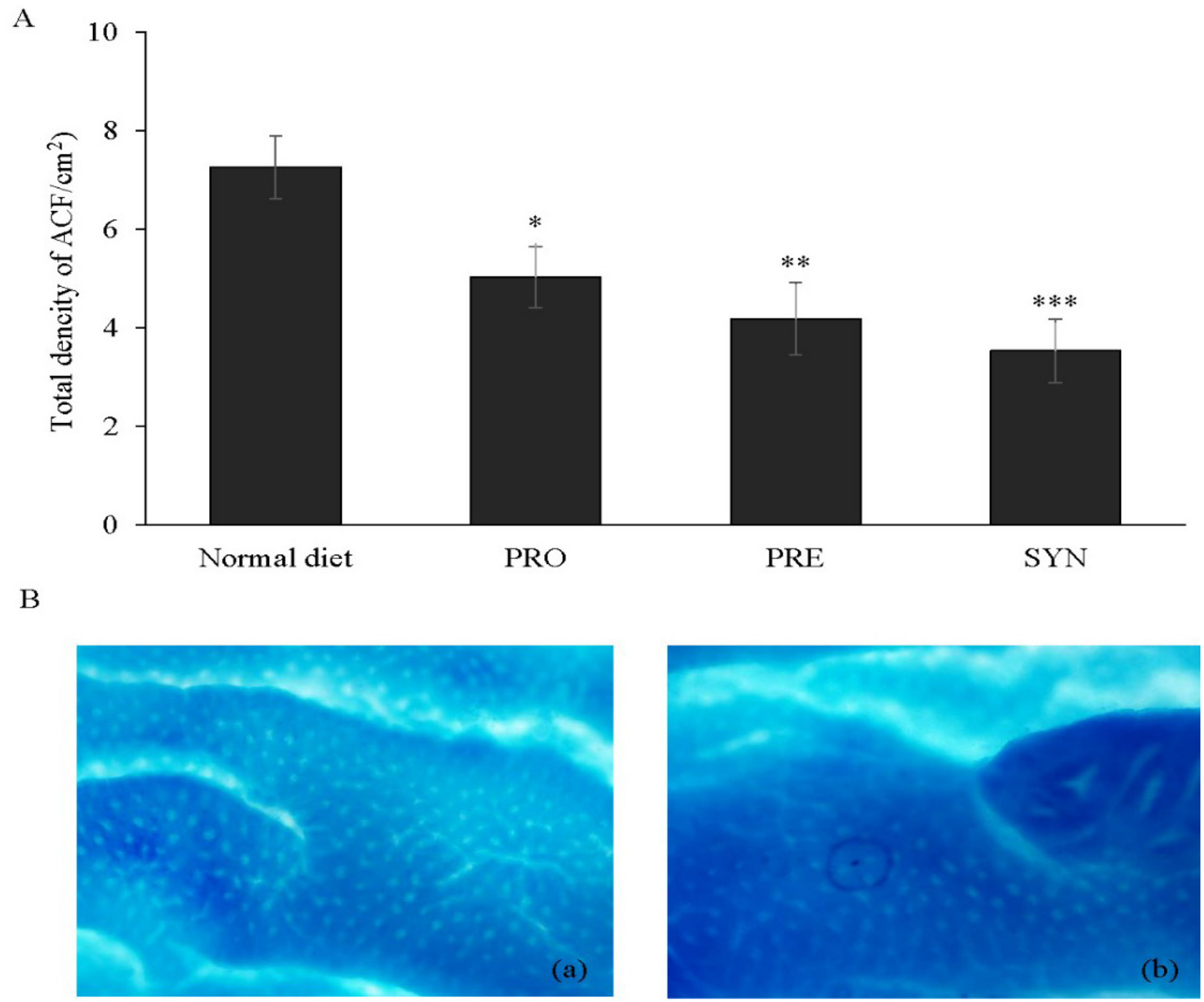

Figure 4. (A) Changes in the density of ACF among the experimental rats. Values are represented as mean \pm SD. ${ }^{\star} p<0.05$ vs control group; ${ }^{* *} p<0.01$ vs control group; ${ }^{* * *} p<0.001$ vs control group. (B) Representative images showing colon of naive (a) and AOM treated (b) rat's tissue samples stained with $0.2 \%$ methylene blue.

\subsection{Aberrant crypt foci}

ACF is one of the markers for colon cancer development in rodents and human, they are the earliest identifiable lesions and are highly correlated with eventual tumor incidence (Ochiai at al., 2014). L. acidophilus showed inhibitory effect on ACF formation in AOM-induced rats (Arimochi et al., 1997). Inulin has been reported to inhibit the formation of ACF (Reddy et al., 1997; Pattananandecha et al., 2016).

The intervention of PRO $(p<0.05)$, PRE $(p<0.01)$ and SYN $(p<0.001)$ were significantly reduced the colonic ACF in AOM-induced rats compared to control. The total density of ACF in control, PRO, PRE, and SYN fed rats were 7.25, 5.02, 4.18 and $3.53 \mathrm{ACF} / \mathrm{cm}^{2}$, respectively (Figure 4). Apparently, the SYN diet decreases the colonic damages more efficiently than other tested reagents in terms of number of ACF.

Synbiotic preparations with oligofructose-enriched inulin + L. rhamnosus, and resistant starch $+B$. lactis more significantly reduced the formation of $\mathrm{ACF}$ than separate prebiotic treatment (Femia et al., 2002; Le Leu et al., 2010). Current study results suggested that the combination of inulin and L. plantarum HII11 suppressed the occurrence of ACF induced by AOM when compared to the administration of either probiotic or prebiotic alone (Figure 4).

\section{Conclusions}

The results of this study revealed that the supplementation of SYN diet (inulin and L. plantarum HII11) protected the AOM-mediated colon cancer induced host by increasing the probiotic population, and organic acids, reducing the pathogen load, microbial enzymes, putrefactive compounds, and ACF formation than either PRO or PRE diets. Moreover, the PRE diets are superior to PRO diets with respect to the assessed parameters. The study results helped to develop a functional food to improve the human immunity and general health, especially against cancerous conditions. 


\section{Acknowledgements}

TP wish to acknowledge the support from Thailand Research Fund through the Royal Golden Jubilee Ph.D. Program (Grant No. PHD/0112/2552), and Graduate School and Faculty of Pharmacy, Chiang Mai University, Chiang Mai, Thailand. BSS acknowledge the Chiang Mai University-Post Doctoral Program for the support.

\section{References}

Anandharaj, M., Sivasankari, B., \& Parveen Rani, R. (2014). Effects of probiotics, prebiotics, and synbiotics on hypercholesterolemia: a review. Chinese Journal of Biology, 2014, 1-7. http://dx.doi. org/10.1155/2014/572754.

Arimochi, H., Kinouchi, T., Kataoka, K., Kuwahara, T., \& Ohnishi, Y. (1997). Effect of intestinal bacteria on formation of azoxymethaneinduced aberrant crypt foci in the rat colon. Biochemical and Biophysical Research Communications, 238(3), 753-757. PMid:9325162. http:// dx.doi.org/10.1006/bbrc.1997.7384.

Burns, A. J., \& Rowland, I. R. (2000). Anti-carcinogenicity of probiotics and prebiotics. Current Issues in Intestinal Microbiology, 1(1), 13-24. PMid:11709850.

Callaway, T. R., Edrington, T. S., Harvey, R. B., Anderson, R. C., \& Nisbet, D. J. (2012). Prebiotics in food animals, a potential to reduce foodborne pathogens and disease. Romanian Biotechnological Letters, 17, 7808-7816.

Center, M. M., Jemal, A., \& Ward, E. (2009). International trends in colorectal cancer incidence rates. Cancer Epidemiology, Biomarkers \& Prevention, 18(6), 1688-1694. PMid:19505900. http://dx.doi. org/10.1158/1055-9965.EPI-09-0090.

Cerini, C., Dou, L., Anfosso, F., Sabatier, F., Moal, V., Glorieux, G., De Smet, R., Vanholder, R., Dignat-George, F., Sampol, J., Berland, Y., \& Brunet, P. (2004). P-cresol, a uremic retention solute, alters the endothelial barrier function in vitro. Thrombosis and Haemostasis, 92(1), 140-150. PMid:15213855.

Chan, D. S., Lau, R., Aune, D., Vieira, R., Greenwood, D. C., Kampman, E., \& Norat, T. (2011). Red and processed meat and colorectal cancer incidence: meta-analysis of prospective studies. PLoS One, 6(6), e20456. PMid:21674008. http://dx.doi.org/10.1371/journal. pone.0020456.

Comalada, M., Bailon, E., de Haro, O., Lara-Villoslada, F., Xaus, J., Zarzuelo, A., \& Gálvez, J. (2006). The effects of short-chain fatty acids on colon epithelial proliferation and survival depend on the cellular phenotype. Journal of Cancer Research and Clinical Oncology, 132(8), 487-497. PMid:16788843. http://dx.doi.org/10.1007/s00432006-0092-x.

Cummings, J. H., Macfarlane, G. T., \& Englyst, H. N. (2001). Prebiotic digestion and fermentation. The American Journal of Clinical Nutrition, 73(2, Suppl), 415S-420S. PMid:11157351.

De Preter, V., Vanhoutte, T., Huys, G., Swings, J., De Vuyst, L., Rutgeerts, P., \& Verbeke, K. (2007a). Effects of Lactobacillus casei Shirota, Bifidobacterium breve, and oligofructose-enriched inulin on colonic nitrogen-protein metabolism in healthy humans. American Journal of Physiology. Gastrointestinal and Liver Physiology, 292(1), G358-G368. PMid:16990449. http://dx.doi.org/10.1152/ajpgi.00052.2006.

De Preter, V., Raemen, H., Cloetens, L., Houben, E., Rutgeerts, P., \& Verbeke, K. (2007b). Effect of dietary intervention with different pre- and probiotics on intestinal bacterial enzyme activities. European Journal of Clinical Nutrition, 62(2), 225-231. PMid:17327863. http:// dx.doi.org/10.1038/sj.ejcn.1602706.
Femia, A. P., Luceri, C., Dolara, P., Giannini, A., Biggeri, A., Salvadori, M., Clune, Y., Collins, K. J., Paglierani, M., \& Caderni, G. (2002). Antitumorigenic activity of the prebiotic inulin enriched with oligofructose in combination with the probiotics Lactobacillus rhamnosus and Bifidobacterium lactis on azoxymethane-induced colon carcinogenesis in rats. Carcinogenesis, 23(11), 1953-1960. PMid:12419846. http://dx.doi.org/10.1093/carcin/23.11.1953.

Fung, K. Y., Brierley, G. V., Henderson, S., Hoffmann, P., McColl, S. R., Lockett, T., Head, R., \& Cosgrove, L. (2011). Butyrate-induced apoptosis in HCT116 colorectal cancer cells includes induction of a cell stress response. Journal of Proteome Research, 10(4), 1860-1869. PMid:21235278. http://dx.doi.org/10.1021/pr1011125.

Gibson, G. R., Scott, K. P., Rastall, R. A., Tuohy, K. M., Hotchkiss, A., Dubert-Ferrandon, A., Gareau, M., Murphy, E. F., Saulnier, D., Loh, G., Macfarlane, S., Delzenne, N., Ringel, Y., Kozianowski, G., Dickmann, R., Lenoir-Wijnkoop, I., Walker, C., \& Buddington, R.. (2010). Dietary prebiotics: current status and new definition. Food Science and Technology Bulletin, 7(1), 1-19. http://dx.doi. org/10.1616/1476-2137.15880.

Gmeiner, M., Kneifel, W., Kulbe, K. D., Wouters, R., De Boever, P., Nollet, L., \& Verstraete, W. (2000). Influence of a synbiotic mixture consisting of Lactobacillus acidophilus 74-2 and a fructo-oligosaccharide preparation on the microbial ecology sustained in a simulation of the human intestinal microbial ecosystem (SHIME reactor). Applied Microbiology and Biotechnology, 53(2), 219-223. PMid:10709985. http://dx.doi.org/10.1007/s002530050011.

Guinane, C. M., \& Cotter, P. D. (2013). Role of the gut microbiota in health and chronic gastrointestinal disease: understanding a hidden metabolic organ. Therapeutic Advances in Gastroenterology, 6(4), 295308. PMid:23814609. http://dx.doi.org/10.1177/1756283X13482996.

Hijova, E., Szabadosova, V., Strojny, L., \& Bomba, A. (2014). Changes chemopreventive markers in colorectal cancer development after inulin supplementation. Bratislavske Lekarske Listy, 115(2), 76-79. PMid:24601699.

Hirschhaeuser, F., Sattler, U. G., \& Mueller-Klieser, W. (2011). Lactate: a metabolic key player in cancer. Cancer Research, 71(22), 6921-6925. PMid:22084445. http://dx.doi.org/10.1158/0008-5472.CAN-11-1457.

Hosseini, E., Grootaert, C., Verstraete, W., \& Van de Wiele, T. (2011). Propionate as a health-promoting microbial metabolite in the human gut. Nurture Review, 69(5), 245-258. PMid:21521227. http://dx.doi. org/10.1111/j.1753-4887.2011.00388.x.

Hughes, R., \& Rowland, I. R. (2000). Metabolic activities of the gut microflora in relation to cancer. Microbial Ecology in Health and Disease, 12(2), 179-185. http://dx.doi.org/10.1080/08910600075 0060431.

Hughes, R., Magee, E. A., \& Bingham, S. (2000). Protein degradation in the large intestine: relevance to colorectal cancer. Current Issues in Intestinal Microbiology, 1(2), 51-58. PMid:11709869.

Huxley, R. R., Ansary-Moghaddam, A., Clifton, P., Czernichow, S., Parr, C. L., \& Woodward, M. (2009). The impact of dietary and lifestyle risk factors on risk of colorectal cancer: a quantitative overview of the epidemiological evidence. International Journal of Cancer, 125(1), 171-180. PMid:19350627. http://dx.doi.org/10.1002/ijc.24343.

Iannitti, T., \& Palmieri, B. (2010). Therapeutical use of probiotic formulations in clinical practice. Clinical Nutrition, 29(6), 701725. PMid:20576332. http://dx.doi.org/10.1016/j.clnu.2010.05.004.

Kolida, S., \& Gibson, G. R. (2011). Synbiotics in health and disease. Annual Review of Food Science and Technology, 2(1), 373-393. PMid:22129388. http://dx.doi.org/10.1146/annurev-food-022510-133739. 
Kolida, S., Tuohy, K., \& Gibson, G. R. (2002). Prebiotic effects of inulin and oligofructose. British Journal of Nutrition, 87(2, Suppl 2), S193-S197. PMid:12088518. http://dx.doi.org/10.1079/BJN/2002537.

Le Leu, R. K., Brown, I. L., Hu, Y., \& Young, G. P. (2003). Effect of resistant starch on genotoxin-induced apoptosis, colonic epithelium, and lumenal contents in rats. Carcinogenesis, 24(8), 1347-1352. PMid:12807738. http://dx.doi.org/10.1093/carcin/bgg098.

Le Leu, R. K., Brown, I. L., Hu, Y., Morita, T., Esterman, A., \& Young, G. P. (2007). Effect of dietary resistant starch and protein on colonic fermentation and intestinal tumourigenesis in rats. Carcinogenesis, 28(2), 240-245. PMid:17166881. http://dx.doi.org/10.1093/carcin/ bgl245.

Le Leu, R., Hu, Y., Brown, I., Woodman, R., \& Young, G. (2010). Synbiotic intervention of Bifidobacterium lactis and resistant starch protects against colorectal cancer development in rats. Carcinogenesis, 31(2), 246-251. PMid:19696163. http://dx.doi.org/10.1093/carcin/bgp197.

Lee, S. M., \& Lee, W. K. (2011). Effects of lactic acid bacteria on intestinal microbial enzyme activity and composition in rats treated with azoxymethane. Journal of Microbiology, 39, 154-161.

Liong, M. T. (2008). Roles of probiotics and prebiotics in colon cancer prevention: postulated mechanisms and in vivo evidence. International Journal of Molecular Sciences, 9(5), 854-863. PMid:19325789. http:// dx.doi.org/10.3390/ijms9050854.

Louis, P., Hold, G. L., \& Flint, H. J. (2014). The gut microbiota, bacterial metabolites and colorectal cancer. Nature Reviews. Microbiology, 12(10), 661-672. PMid:25198138. http://dx.doi.org/10.1038/nrmicro3344.

McCall, I. C., Betanzos, A., Weber, D. A., Nava, P., Miller, G. W., \& Parkos, C. A. (2009). Effects of phenol on barrier function of a human intestinal epithelial cell line correlate with altered tight junction protein localization. Toxicology and Applied Pharmacology, 241(1), 61-70. PMid:19679145. http://dx.doi.org/10.1016/j.taap.2009.08.002.

Moreno de LeBlanc, A., \& Perdigón, G. (2005). Reduction of betaglucuronidase and nitroreductase activity by yoghurt in a murine colon cancer model. Biocell, 29(1), 15-24. PMid:15954463.

Noack, J., Timm, D., Hospattankar, A., \& Slavin, J. (2013). Fermentation profiles of wheat dextrin, inulin and partially hydrolyzed guar gum using an in vitro digestion pretreatment and in vitro batch fermentation system model. Nutrients, 5(5), 1500-1510. PMid:23645025. http:// dx.doi.org/10.3390/nu5051500.

Nowak, A., \& Libudzisz, Z. (2006). Influence of phenol, p-cresol and indole on growth and survival of intestinal lactic acid bacteria. Anaerobe, 12(2), 80-84. PMid:16701619. http://dx.doi.org/10.1016/j. anaerobe.2005.10.003.

Ochiai, M., Hippo, Y., Izumiya, M., Watanabe, M., \& Nakagama, H. (2014). Newly defined aberrant crypt foci as a marker for dysplasia in the rat colon. Cancer Science, 105(8), 943-950. PMid:24827115. http://dx.doi.org/10.1111/cas.12446.

Ohtani, N. (2015). Microbiome and cancer. Seminars in Immunopathology, 37(1), 65-72. PMid:25404117. http://dx.doi.org/10.1007/s00281014-0457-1.

Ouwehand, A. C., Lagstrom, H., Suomalainen, T., \& Salminen, S. (2002). Effect of probiotics on constipation, fecal azoreductase activity and fecal mucin content in the elderly. Annals of Nutrition \& Metabolism, 46(3-4), 159-162. PMid:12169860. http://dx.doi. org/10.1159/000063075.

Pan, X., Chen, F., Wu, T., Tang, H., \& Zhao, Z. (2009). Prebiotic oligosaccharides change the concentrations of short-chain fatty acids and the microbial population of mouse bowel. Journal of Zhejiang University. Science. B., 10(4), 258-263. PMid:19353743. http://dx.doi.org/10.1631/jzus.B0820261.
Pattananandecha, T., Sirilun, S., Duangjitcharoen, Y., Sivamaruthi, B. S., Suwannalert, P., Peerajan, S., \& Chaiyasut, C. (2016). Hydrolyzed inulin alleviates the azoxymethane-induced preneoplastic aberrant crypt foci by altering selected intestinal microbiota in Sprague-Dawley rats. Pharmaceutical Biology, 54(9), 1596-1605. PMid:26794346. http://dx.doi.org/10.3109/13880209.2015.1110597.

Pattananandecha, T., Sirilun, S., Sivamaruthi, B. S., Suwannalert, P., Peerajan, S., \& Chaiyasut, C. (2015). Hydrolyzed Inulin with Different Degree of Polymerization as Prebiotic for Lactobacillus plantarum. Journal of Pure \& Applied Microbiology, 9(2), 973-979.

Pool-Zobel, B. L., Selvaraju, V., Sauer, J., Kautenburger, T., Kiefer, J., Richter, K. K., Soom, M., \& Wölfl, S. (2005). Butyrate may enhance toxicological defence in primary, adenoma and tumor human colon cells by favourably modulating expression of glutathione S-transferases genes, an approach in nutrigenomics. Carcinogenesis, 26(6), 10641076. PMid:15746163. http://dx.doi.org/10.1093/carcin/bgi059.

Pourhoseingholi, M. A. (2012). Increased burden of colorectal cancer in Asia. World Journal of Gastrointestinal Oncology, 4(4), 68-70. PMid:22532878. http://dx.doi.org/10.4251/wjgo.v4.i4.68.

Propst, E. L., Flickinger, E. A., Bauer, L. L., Merchen, N. R., \& Fahey, G. C. Jr (2003). A dose-response experiment evaluating the effects of oligofructose and inulin on nutrient digestibility, stool quality, and fecal protein catabolites in healthy adult dogs. Journal of Animal Science, 81(12), 3057-3066. PMid:14677862. http://dx.doi. org/10.2527/2003.81123057x.

Rafii, F., Franklin, W., \& Cerniglia, C. E. (1990). Azoreductase activity of anaerobic bacteria isolated from human intestinal microflora. Applied and Environmental Microbiology, 56(7), 2146-2151. PMid:2202258.

Raman, M., Ambalam, P., Kondepudi, K. K., Pithva, S., Kothari, C., Patel, A. T., Purama, R. K., Dave, J. M., \& Vyas, B. R. (2013). Potential of probiotics, prebiotics and synbiotics for management of colorectal cancer. Gut Microbes, 4(3), 181-192. PMid:23511582. http://dx.doi. org/10.4161/gmic.23919.

Reddy, B., Hamid, R., \& Rao, C. V. (1997). Effect of dietary oligofructose and inulin on colonic preneoplastic aberrant crypt foci inhibition. Carcinogenesis, 18(7), 1371-1374. PMid:9230282. http://dx.doi. org/10.1093/carcin/18.7.1371.

Riboli, E., \& Norat, T. (2003). Epidemiologic evidence of the protective effect of fruit and vegetables on cancer risk. The American Journal of Clinical Nutrition, 78(3, Suppl), 559s-569s. PMid:12936950.

Rossi, M., Corradini, C., Amaretti, A., Nicolini, M., Pompei, A., Zanoni, S., \& Matteuzzi, D. (2005). Fermentation of fructooligosaccharides and inulin by bifidobacteria: a comparative study of pure and fecal cultures. Applied and Environmental Microbiology, 71(10), 6150-6158. PMid:16204533. http://dx.doi.org/10.1128/AEM.71.10.6150-6158.2005.

Rowland, I., Rumney, C., Coutts, J., \& Lievense, L. (1998). Effect of Bifidobacterium longum and inulin on gut bacterial metabolism and carcinogen-induced aberrant crypt foci in rats. Carcinogenesis, 19(2), 281-285. PMid:9498277. http://dx.doi.org/10.1093/carcin/19.2.281.

Ruemmele, F. M., Schwartz, S., Seidman, E. G., Dionne, S., Levy, E., \& Lentze, M. J. (2003). Butyrate induced Caco-2 cell apoptosis is mediated via the mitochondrial pathway. Gut, 52(1), 94-100. PMid:12477768. http://dx.doi.org/10.1136/gut.52.1.94.

Schwabe, R. F., \& Jobin, C. (2013). The microbiome and cancer. Nature Reviews. Cancer, 13(11), 800-812. PMid:24132111. http://dx.doi. org/10.1038/nrc3610.

Siavoshian, S., Segain, J., Kornprobst, M., Bonnet, C., Cherbut, C., Galmiche, J., \& Blottiere, H. (2000). Butyrate and trichostatin A effects on the proliferation/differentiation of human intestinal epithelial cells: induction of cyclin D3 and p21 expression. Gut, 46(4), 507-514. PMid:10716680. http://dx.doi.org/10.1136/gut.46.4.507. 
Slavin, J. (2013). Fiber and prebiotics: mechanisms and health benefits. Nutrients, 5(4), 1417-1435. PMid:23609775. http://dx.doi.org/10.3390/ nu5041417.

Swanson, K. S., Grieshop, C. M., Flickinger, E. A., Bauer, L. L., Healy, H. P., Dawson, K. A., Merchen, N. R., \& Fahey, G. C. Jr (2002). Supplemental fructo-oligosaccharides and mannan-oligosaccharides influence immune function, ileal and total tract nutrient digestibilities, microbial populations and concentrations of protein catabolites in the large bowel of dogs. The Journal of Nutrition, 132(5), 980-989. PMid:11983825.

Uccello, M., Malaguarnera, G., Basile, F., D’agata, V., Malaguarnera, M., Bertino, G., Vacante, M., Drago, F., \& Biondi, A. (2012). Potential role of probiotics on colorectal cancer prevention. BMC Surgery, 12(Suppl 1), S35. PMid:23173670. http://dx.doi.org/10.1186/14712482-12-S1-S35.

Van, M. H. M. C., Meyer, P. D., \& Venema, K. (2003). The effect of various inulins and Clostridium difficile on the metabolic activity of the human colonic microbiota in vitro. Microbial Ecology in Health and Disease, 15(2-3), 137-144. http://dx.doi.org/10.1080/08910600310018959.

Waldecker, M., Kautenburger, T., Daumann, H., Busch, C., \& Schrenk, D. (2008). Inhibition of histone-deacetylase activity by short-chain fatty acids and some polyphenol metabolites formed in the colon. The Journal of Nutritional Biochemistry, 19(9), 587-593. PMid:18061431. http://dx.doi.org/10.1016/j.jnutbio.2007.08.002.

Windey, K., De Preter, V., \& Verbeke, K. (2012). Relevance of protein fermentation to gut health. Molecular Nutrition \& Food Research, 56(1), 184-196. PMid:22121108. http://dx.doi.org/10.1002/mnfr.201100542.

Wollowski, I., Rechkemmer, G., \& Pool-Zobel, B. L. (2001). Protective role of probiotics and prebiotics in colon cancer. The American Journal of Clinical Nutrition, 73(2, Suppl), 451s-455s. PMid:11157356.

Yoon, H., Benamouzig, R., Little, J., François-Collange, M., \& Tomé, D. (2000). Systematic review of epidemiological studies on meat, dairy products and egg consumption and risk of colorectal adenomas. European Journal of Cancer Prevention, 9(3), 151-164. PMid:10954254. http://dx.doi.org/10.1097/00008469-200006000-00002. 